Seminário de Pesquisa

Programa de Pós-Graduação

Design FAU USP

\title{
Design de serviço no ensino superior a distância: análise crítica e sistematizadora da interação de instituições de ensino superior paulistanas selecionadas com seus usuários
}

Sérgio Kooji Kamimura, Luís Cláudio Portugal do Nascimento

\author{
design de serviço; ensino a distância; ensino superior
}

O ensino a distância (EaD) refere-se a uma nova forma de se oferecer educação, pública ou privada, principalmente no nível superior. Esta pesquisa busca identificar e sistematizar aspectos relevantes do design de serviço observáveis em práticas de ensino a distância, entre 2021 e 2022, em instituições selecionadas de ensino superior na cidade de São Paulo, no que se refere à experiência vivenciada por seus alunos usuários, especialmente quanto à aquisição de conhecimento (incluindo-se rotinas didáticas e materiais pedagógicos), eficiência e ergonomia da interface de plataformas virtuais utilizadas, características de interações interpessoais, qualidade de instalações físicas (caso aplicável, em alguns cenários),

Curso

Doutorado

\section{Linha de Pesquisa}

Design: Processos e Linguagens

\section{Sérgio Kooji Kamimura}

Professor na FMU/FiamFaam, mestre pela Fau-usp (2015) e bacharel em arquitetura e urbanismo pela Fau-usp (1982). e-mail: sergiokamimura@usp.br Lattes: http://lattes.cnpq. $\mathrm{br} / 6126679626474398$ Orcid: https://orcid.org/00000001-9292-5593

\section{Luís Cláudio Portugal \\ do Nascimento}

Professor da Fau-usp, doutor em ensino do design pela New York University (1997), mestre pela École Nationale Supérieure d'Arts et Métiers, Paris (1987), e bacharel em desenho industrial e comunicação visual pela Escola Superior de Desenho Industrial da Uerj (1983).

e-mail: claudioportugal@usp.br

Lattes: http://lattes.cnpq. br/2797773827825547

Orcid: https://orcid.org/0000-

0003-4586-1747 além de aspectos pertinentes relativos a procedimentos, normas, valores e rotinas institucionais mais gerais, com base na visão de estudantes, professores, funcionários e especialistas teóricos, complementadas por observações do pesquisador, com vistas à formulação propositiva de critérios, parâmetros, diretrizes e recomendações técnicas que possam orientar processos de projeto e sistemáticas de avaliação do design de serviço de cursos a distância em instituições de ensino superior. Tem como método, observações no campo, descrições dos processos dos serviços de educação por meio de "mapas de jornada", entrevistas (semiestruturadas e em profundidade) individuais e com grupos focais, e questionários com usuários. Os resultados serão categorizados, buscando-se padrões abstratos de associações, que possibilitarão elaborar critérios e parâmetros para a criação de um guia de orientação para aplicação do design de serviços no ensino a distância em instituições de educação superior brasileiras. 


\section{Service design in distance higher education: critical and systematic analysis of the interaction of selected higher education institutions in São Paulo with its users}

Sérgio Kooji Kamimura, Luís Cláudio Portugal do Nascimento

service design; e-learning; higher education

E-learning refers to a new way of offering education, public or private, mainly at higher education. This research seeks to identify and systematize relevant aspects of service design observable in e-learning practices, in 2021 and 2022, in selected institutions of higher education in the city of São Paulo, in terms of the experience lived by their student users, especially regarding the knowledge acquisition (including didactic routines and pedagogical materials), efficiency and ergonomics of the interface of virtual platforms used, characteristics of interpersonal interactions, quality of physical installations (if applicable, in some scenarios), in addition to relevant aspects related to procedures, more general norms, values and institutional routines, based on the view of students, professors, staff and theoretical experts, complemented by the researcher's observations, with a view to proposing formulating criteria, parameters, guidelines and technical recommendations that can guide design processes and systematic evaluation of design and service of e-learning in higher education institutions. It has as method, observations in the field, descriptions of the processes of the education services through "journey maps", interviews (semistructured and in depth) individual and with focus groups, and questionnaires with users. The results will be categorized, looking for abstract patterns of associations, which will make it possible to develop criteria and parameters that enable the creation of an orientation guide for the application of service design in e-learning in Brazilian higher education institutions.

\section{Referências | References \\ ANGROSINO, M. 2009. Etnografia e observação participante. Porto Alegre: Artmed. \\ BAUER, M. W. \& GASKELL, G. 2012. Pesquisa qualitativa com texto, imagem e som. Um manual prático. Petrópolis: Vozes.}

\section{Luís Cláudio Portugal}

do Nascimento

Professor at Fau-usp. He holds a Ph.D. in art education from New York University (1997), a Masters Degree from École Nationale Supérieure d'Arts et Métiers, Paris (1987), and a Bachelors Degree in Graphic and Industrial Design from Uerj's Escola Superior de Desenho Industrial (1983).

e-mail: claudioportugal@usp.br

Lattes: http://lattes.cnpq. br/2797773827825547

Orcid: https://orcid.org/00000003-4586-1747

RAMASWAMY, R. 1996. Design and management of service processes: keeping customers for life. Boston: Addison-Wesley Publishing.

SANTOS, S. M. 2015. O desempenho das universidades brasileiras nos rankings internacionais: áreas de destaque da produção científica brasileira. Tese de doutorado, ECA USP, São Paulo.

STICKDORN, M \& SCHNEIDER, J. 2014. Isto é design thinking de serviços: fundamentos - ferramentas - casos. Porto Alegre: Bookman. 